\title{
Paclobutrazol and phenoxaprope-P-ethyl potential as growth regulator in Carpet grass Plus ${ }^{\circledR}$
}

\author{
Mariana Moreira Melero ${ }^{1}\left(\mathbb{D}\right.$, Patrick Luan Ferreira dos $\operatorname{Santos}^{2^{*}}\left(\mathbb{0}\right.$, Jéssica Cristina Meira Bezerra ${ }^{1}\left(\mathbb{0}\right.$, Bruno Horschut de Lima ${ }^{1}(\mathbb{0}$, \\ Maximiliano Kawahata Pagliarini ${ }^{3}$ (), Regina Maria Monteiro de Castilho ${ }^{1}{ }^{10}$
}

\footnotetext{
${ }^{1}$ Universidade Estadual Paulista (UNESP), Faculdade de Engenharia de Ilha Solteira, Ilha Solteira-SP, Brazil.

${ }^{2}$ Universidade Estadual Paulista (UNESP), Faculdade de Ciências Agronômicas, Botucatu-SP, Brazil.

${ }^{3}$ Universidade Federal da Grande Dourados, Fazenda Experimental de Ciências Agrárias, Dourados-MS, Brazil.
}

\begin{abstract}
Mowing is a fundamental management for turfgrass development. However, this operation has a higher cost, requiring alternatives to mechanical handling, such as growth regulators use. Thus, the objective was to evaluate the use of paclobutrazol and phenoxaprope-P-ethyl as growth regulators in Carpet grass Plus ${ }^{\circledR}$. The experiment was performed in full sun, in the northwest region of São Paulo state, from January to March 2020. The grass used was planted in black plastic containers $(50 \times 17 \mathrm{~cm}$, with a height of 15 $\mathrm{cm}$, totalling $11 \mathrm{~L}$ of volume), previously prepared with a mixture of soil + sand $(2: 1)$. The experimental design was completely randomized, consisting of two doses of paclobutrazol $\left(1.0\right.$ and $\left.2.0 \mathrm{~mL} \mathrm{~L}^{-1}\right)+$ control and two doses of phenoxaprope-P-ethyl (6.25 and $\left.12.5 \mu \mathrm{L} \mathrm{L}^{-1}\right)+$ control. Leaf chlorophyll index, digital image analysis and fresh leaf mass were evaluated. It was observed that for Carpet grass Plus ${ }^{\circledR}$, there was paclobutrazol effect when used as a growth regulator, with the recommended dose of $2 \mathrm{ml} \mathrm{L}^{-1}$ due to its residual effect up to 35 days in reducing fresh mass, without changing the concentration of leaf chlorophyll and green colour. Phenoxaprope-P-ethyl, on the other hand, had an effect as a growth regulator for the studied species, when used in the dose of $6.25 \mu \mathrm{L} \mathrm{L}^{-1}$.
\end{abstract}

Keywords: Axonopus fissifolius, turfgrass, embankments.

\section{Resumo}

Potencial do paclobutrazol e fenoxaprope-P-etílico como regulador de crescimento em grama São Carlos Plus ${ }^{\circledR}$

O corte é o um manejo fundamental para o desenvolvimento do gramado. Contudo, essa operação apresenta um alto custo, sendo necessárias alternativas ao manejo mecânico, tal como o uso de reguladores de crescimento. Assim, o objetivo foi avaliar o uso de paclobutrazol e fenoxaprope-P-etílico como reguladores de crescimento em grama São Carlos Plus ${ }^{\circledR}$. O experimento foi realizado a pleno sol, no noroeste paulista, durante os meses de janeiro a março de 2020. A grama utilizada foi implantada em contêineres de plástico preto $(50 \times 17 \mathrm{~cm}$, com altura de $15 \mathrm{~cm}$, totalizando um volume de 11 litros), previamente preparados com a mistura de solo + areia (2:1). O delineamento experimental foi inteiramente casualizado, composto por duas doses de Paclobutrazol $(1,0$ e $2,0 \mathrm{~mL}$ $\left.\mathrm{L}^{-1}\right)+$ controle e duas doses de fenoxaprope-P-etílico $\left(6,25\right.$ e $\left.12,5 \mu \mathrm{L} \mathrm{L}^{-1}\right)+$ controle. Foram avaliados o índice de clorofila foliar, análise por imagem digital e massa fresca das folhas. Observou-se que para a grama São Carlos Plus ${ }^{\circledR}$, houve efeito do Paclobutrazol quando utilizado como regulador de crescimento, sendo a dose recomendada de $2 \mathrm{ml} \mathrm{L}^{-1}$ devido a seu efeito residual de até 35 dias na redução de massa fresca e seca, sem alterar a concentração de clorofila foliar e coloração verde. Já o fenoxaprope-P-etílico apresentou efeito como regulador de crescimento para a espécie estudada, quando utilizado na dose de $6,25 \mu \mathrm{L} \mathrm{L}^{-1}$.

Palavras-chave: Axonopus fissifolius, gramados, taludes.

\section{Introduction}

The use of grass as a permanent vegetation covering on soil surfaces has been an agricultural practice made for several purposes, which can be landscape, recreational, sporting, ornamental and environmental lawns (Santos et al., 2016, Souza et al., 2016; Oliveira et al., 2018).

In order to minimize environmental impacts resulting from human activities and reduce the negative aspect of these activities, which can result in soil modification and

*Corresponding author: patricklfsantos@gmail.com 
degradation, earthworks are performed, plant coverings planting, where the use of turf is recommended (Antoniolli, 2019). The construction of roads and other works that require earthmoving and with the occurrence of high precipitation rate in short periods may lead to the maximization of problems related to embankments instability (Castro et al., 2015; Souza et al., 2016; Antoniolli, 2019). Slope recovery through regreening technique (revegetation), in addition to protecting the soil against direct rain impact, allows the area to stabilize through plant root system, creating an environment with deposition of nutritional organic matter, and water conservative effect (Antoniolli, 2019). In Brazil, the species most recommended for this purpose are those that require low maintenance, due to slower growth and have resistance to droughts (Godoy et al., 2012; Souza et al., 2016) such as the native Carpet grass (Axonopus fissifolius).

Carpet grass has its origin centre in South America, in southern region of Brazil, where it is also known as "Curitibana". It is characterized by having a stoloniferous growth habit, with broad and hairy leaves, with a bright green colour (Godoy et al., 2012, Dias et al., 2015) and 'Plus ${ }^{\circledR}$ ' is indicated for projects that include areas in full sun and also those with low light (Itograss, 2020). However, mowing is necessary, as it avoids dry matter accumulation, contributing to a lower risk of fire and its control, if necessary (Affonso and Freitas, 2003).

However, according to Kreuser (2015), mowing may be difficult due to the embankment slope, and also, resulting in higher expenses (Santos and Castilho, 2018). Thus, an alternative to this management would be the use of plant growth regulators (Dinalli et al., 2015; Marchi et al., 2017; Dias et al., 2019; Gazola et al., 2019). It has the function slower the plant growth, without causing visible damage, such as necrotic spots of phytotoxicity, discoloration or thinning, but allowing the maintenance of its aesthetics and characteristic green colour (Gazola et al., 2016; Dias et al., 2019).

However, in Brazil does not have any product registered as a growth regulator for grass, so it is necessary to search for more information (Dias et al., 2019). Paclobutrazol is a well-studied regulator, and registered for several species of grass in the European Union (Semillas Fitó, 2010) and in the USA (McEloroy, 2012). It is a compound of triazole group and reduces plant growth by blocking the action of the enzyme ent-kaurene oxidase, which inhibits the conversion of ent-kaurene to ent-kaurenol, which prevents the formation of any type of gibberellin (Glab et al., 2020). On the other hand, for several products such as trinexapac-ethyl and prohexadione-calcium and the herbicides, imazethapyr, metsulfuron-methyl, imazaquin and glyphosate (Dinalli et al., 2015; Marchi et al., 2017; Queiroz et al., 2017; Dias et al., 2019; Gazola et al., 2019) there are reports as being used in lawns for growth control. However, for phenoxaprope-P-ethyl (post-emergent selective herbicide, which has phenoxaprope-P-ethyl as an active ingredient, which acts as an ACCase enzyme inhibitor) (Bayer, 2019) there is no use for this purpose.
In this context, the objective was to evaluate the use of paclobutrazol and phenoxaprope-P-ethyl doses as growth regulators in Carpet grass Plus ${ }^{\circledR}$.

\section{Material and Methods}

The experiment was conducted in the field, at Northwest region of São Paulo state (at the elevation of $335 \mathrm{~m}$ ), in full sun, in a black plastic container, from January 21 to March 16, 2020 (Mean temperature of $26.8^{\circ} \mathrm{C}$, mean relative humidity of $85.1 \%$ and accumulated precipitation of 385.2 $\mathrm{mm})$.

Two chemical products were used: paclobutrazol (250 $\mathrm{g} \mathrm{L}^{-1}$ of active ingredient) and phenoxaprope-P-ethyl (110 $\mathrm{g} \mathrm{L}^{-1}$ of active ingredient). The experimental design chosen was completely randomized, with three treatments and three replicates for each product, on different evaluation dates. Products were diluted in two concentrations being 1.0 and $2.0 \mathrm{ml} \mathrm{L}^{-1}+$ control $\left(0 \mathrm{ml} \mathrm{L}^{-1}\right)$ for paclobutrazol and two concentrations $\left(6.25\right.$ and $\left.12.5 \mu \mathrm{L} \mathrm{L}^{-1}\right)+$ control $\left(0 \mu \mathrm{L} \mathrm{L}^{-1}\right)$ for phenoxaprope-P-ethyl. The doses obtained were in accordance with manufacturers recommendations (Bayer, 2019), corrected for the area of the experimental plots.

For experiment installation, made on January $21^{\text {st }}$, Carpet grass Plus ${ }^{\circledR}$ sod (A. fissifolius) were used, with a dimension of $65 \mathrm{~cm}$ (length) and $40 \mathrm{~cm}$ (width) planted on black plastic containers $(50 \mathrm{~cm} \times 17 \mathrm{~cm}$, with a height of $15 \mathrm{~cm}$, totalling $11 \mathrm{~L}$ volume), previously prepared with a mixture of soil and sand, proportion 2:1. On the same day, fertilization with commercial product was performed, $10 \mathrm{~g} \mathrm{~L}^{-1}$ of products were diluted, and $2 \mathrm{~L}$ per container was applied, as recommended by manufacturer; the composition of fertilizer was: $13 \% \mathrm{~N} ; 5 \% \mathrm{P}_{2} \mathrm{O}_{5} ; 13 \% \mathrm{~K}_{2} \mathrm{O}$; $1 \% \mathrm{Ca} ; 0.04 \% \mathrm{~B} ; 0.08 \% \mathrm{Mn} ; 1 \% \mathrm{Mg} ; 0.05 \% \mathrm{Cu} ; 0.005 \%$ Mo; $5 \% \mathrm{~S} ; 0.2 \% \mathrm{Fe}$ and $0.15 \% \mathrm{Zn}$.

On January 29, 2020, after turfgrass mowing to standardize the area, the product was applied. Weed control was not necessary and watering was daily with $2 \mathrm{~L}$ of water per container, in the late afternoon, using a watering can.

The evaluations assessed were:

a) Leaf chlorophyll index (LCI) reading were taken, on at 7, 15 and 35 days after products application (DAA), respectively. For this purpose, a manual chlorophyll meter (at LEAF) was used, collecting at 3 points per experimental plot, measured in the middle third of leaves.

b) Analysis by digital image: At 15 and 35 DAA, photographs of the areas were taken with $12 \mathrm{Mp}$ camera, 1 meter of distance; these images were transferred to a computer, and with Adobe Fireworks ${ }^{\circledR}$ program, RGB value (Blue, Green and Red) of each image was verified. As only green $(\mathrm{G})$ component does not define green colour, depending also on red $(\mathrm{R})$ and blue $(\mathrm{B})$ components, the RGB results were compiled into an electronic spreadsheet in MS Excel and converted to HSB values (hue, saturation and brightness), and with these, Dark Green Colour Index (DGCI) was calculated, which varies from 0 - 1 (Karcher and Richardson, 2003). 
c) Fresh leaf mass: the material was collected manually, using scissors to remove all leaves from treatments. Thus, after cutting, the material was stored in a brown paper bag and weighed to obtain the fresh mass. The samplings were performed on 0 (before product application), and at 15 and 35 DAA.

The collected data were submitted to analysis of variance and, subsequently, the means were compared by Tukey test at $5 \%$ of significance using SISVAR (Ferreira, 2019).

\section{Results and Discussion}

For fresh mass variable (Table 1), an interaction between doses and sampling dates was observed, where treatments with Paclobutrazol differed by $0.46 \mathrm{Kg} \mathrm{m}^{-2}$ (60.52\%), when compared to control to the dose of $2.0 \mathrm{~mL} \mathrm{~L}^{-1}$ at 15 days after application (DAA). At 35 DAA there was no statistical difference, however, the difference between the highest dose and the control was $0.22 \mathrm{~kg} \mathrm{~m}^{-2}(53.66 \%)$.

Although the doses of 1.0 and $2.0 \mathrm{~mL} \mathrm{~L}^{-1}$ did not differ from each other, it can be observed that with increasing concentrations, there is a decrease of fresh mass, which is explained by its mechanism of action. Paclobutrazol blocks enzyme ent-kaurene oxidase action inhibiting the conversion of ent-kaurene to ent-kaurenol, which prevents any type of gibberellin formation (Glab et al., 2020), creating more compact leaf (McElroy, 2012). Working with 'TifEagle' (C. dactylon x C. transvaalensis), McCullough et al. (2004) observed $86 \%$ of reduction in grass clippings amount with two Paclobutrazol applications, with intervals of three weeks between them. At the present study the maximum reduction achieved was $60.52 \%$ with just one application, thus inferring that with a new application, this percentage may be higher.

Still, from the results obtained in the present study (Table 1), it appears that there is a residual effect of up to 35 days of the product (Table1). In 'Tifway 419' bermuda grass (Cynodon dactylon x C. transvaaalensis) the use of Paclobutrazol had an effect within 49 days after application (Johnson, 1992), corroborating to present study.

In the case of phenoxaprope-P-ethyl (Table 1), the used dose that presented the best result, decreasing the value of leaves fresh mass was $6.25 \mu \mathrm{L} \mathrm{L}^{-1}$ at $15 \mathrm{DAA}$, reducing by $0.20 \mathrm{~kg} \mathrm{~m}^{-2}(31.25 \%)$.

Table 1. Fresh mass of Carpet grass Plus ${ }^{\circledR}$ clippings before and after application of paclobutrazol and phenoxaprope-p-ethyl.

\begin{tabular}{|c|c|c|c|}
\hline Doses & O DAA & 15 DAA & 35 DAA \\
\hline \multirow{2}{*}{$\mathbf{m l ~ L} \mathbf{L}^{-1}$} & \multicolumn{3}{|c|}{$\mathrm{Kg} \mathrm{m}^{-2}$} \\
\hline & \multicolumn{3}{|c|}{ Paclobutrazol } \\
\hline 0 & $0.54 \mathrm{aAB}$ & $0.76 \mathrm{aA}$ & $0.41 \mathrm{aB}$ \\
\hline 1.0 & $0.58 \mathrm{aA}$ & $0.45 \mathrm{bAB}$ & $0.30 \mathrm{aB}$ \\
\hline 2.0 & $0.52 \mathrm{aA}$ & $0.30 \mathrm{bAB}$ & $0.19 \mathrm{aB}$ \\
\hline CVC line & \multicolumn{3}{|c|}{0.23} \\
\hline CVC column & \multicolumn{3}{|c|}{0.23} \\
\hline CV $(\%)$ & \multicolumn{3}{|c|}{24.95} \\
\hline $\mathrm{F}$ dose $\mathrm{x}$ time & \multicolumn{3}{|c|}{$3.158^{*}$} \\
\hline $\boldsymbol{\mu} \mathbf{I} \mathbf{L}^{-1}$ & \multicolumn{3}{|c|}{ Phenoxaprope-p-ethyl } \\
\hline 0 & $0.51 \mathrm{aA}$ & $0.64 \mathrm{aA}$ & $0.33 \mathrm{aB}$ \\
\hline 6.25 & $0.63 \mathrm{aA}$ & $0.44 \mathrm{bB}$ & $0.27 \mathrm{aB}$ \\
\hline 12.5 & $0.56 \mathrm{aAB}$ & $0.58 \mathrm{abA}$ & $0.40 \mathrm{aB}$ \\
\hline CVC line & \multicolumn{3}{|c|}{0.17} \\
\hline CVC column & \multicolumn{3}{|c|}{0.17} \\
\hline CV $(\%)$ & \multicolumn{3}{|c|}{17.28} \\
\hline $\mathrm{F}$ dose $\mathrm{x}$ time & \multicolumn{3}{|c|}{$3.08^{*}$} \\
\hline
\end{tabular}

Means followed by the same lowercase letter in the column and uppercase in the line do not differ by Tukey test at $5 \%$ of significance. DAA: Days after application. 
At 35 DAA, there was no difference between treatments, however, $6.25 \mu \mathrm{L} \mathrm{L}^{-1}$ dose showed the lowest reduction when compared to the control which presented $0.06 \mathrm{~kg} \mathrm{~m}^{-2}(18.18 \%)$. This decrease may be associated with the product action mechanism, since the active ingredient (phenoxaprope-p-ethyl) acts on plants at growth points, inhibiting Acetyl Coenzyme Ase (ACCase) and, consequently, lipid biosynthesis. This reaction leads to reduced growth, increased membrane permeability and ultra-structural effects on cells, and the growth of roots and shoots is halted (Bayer, 2019).

The highest phenoxaprope-p-ethyl used dose $(12.5 \mu \mathrm{L}$ $\mathrm{L}^{-1}$ ) showed small reduction at $15 \mathrm{DAA}$ of $0.06 \mathrm{Kg} \mathrm{m}^{-2}$ (9.37\%), however at 35 DAA presented the highest value, among treatments. In other words, there was an increase of $0.07 \mathrm{~kg} \mathrm{~m}^{-2}(21.21 \%)$ in mass production. This fact might might be explained because, instead of reducing growth, sub-dose caused a hormone effect, there was the residual effect with a very low dose, which instead of reducing growth, stimulated plant to develop further. Some chemical products, whose main purpose is to be used an herbicide, if used in low concentrations, may cause this effect (Marques et al., 2020), thus characterizing a biphasic dose-response phenomenon, as it presents low-dose stimulation response and high-dose inhibition (Silva et al., 2016), which may have occurred in the present study. Furthermore, according to Dias et al. (2019), the effects of herbicides as growth regulators depend on several factors, such as plant species, used herbicides dose, application time, number of applications and environmental conditions at the time of application.

The values of leaf chlorophyll index (LCI) (Table 2) showed a significant interaction between doses and samplings performed for paclobutrazol. Up to $7 \mathrm{DAA}$, doses showed no difference comparing to control, however, after 15 DAA, it is noted that LCI has decreased in relation to control and also differing from doses 1.0 and $2.0 \mathrm{ml} \mathrm{L}^{-1}$. Similar fact occurred at 35 DAA, where control differed statistically from the highest dose, presenting the lowest value of all analyses performed.

Table 2. Leaf chlorophyll index (LCI) of Carpet grass Plus ${ }^{\circledR}$ before and after application of paclobutrazol and phenoxapropep-ethyl.

\begin{tabular}{|c|c|c|c|c|c|}
\hline Doses & Installation & Day of application & 7 DAA & 15 DAA & 35 DAA \\
\hline \multirow{2}{*}{$\mathrm{ml} \mathrm{L} \mathrm{L}^{-1}$} & \multicolumn{5}{|c|}{ LCI } \\
\hline & \multicolumn{5}{|c|}{ Paclobutrazol } \\
\hline 0 & $49.47 \mathrm{aAB}$ & $52.63 \mathrm{aA}$ & $52.40 \mathrm{aA}$ & $46.93 \mathrm{bB}$ & $38.60 \mathrm{bC}$ \\
\hline 1.0 & $49.07 \mathrm{aB}$ & $53.10 \mathrm{aAB}$ & $54.03 \mathrm{aA}$ & $52.26 \mathrm{aAB}$ & $40.77 \mathrm{abC}$ \\
\hline 2.0 & $46.37 \mathrm{aBC}$ & $50.80 \mathrm{aAB}$ & $51.77 \mathrm{aA}$ & $53.50 \mathrm{aA}$ & $42.77 \mathrm{aC}$ \\
\hline CVC line & \multicolumn{5}{|c|}{4.7} \\
\hline CVC column & \multicolumn{5}{|c|}{4.00} \\
\hline CV (\%) & \multicolumn{5}{|c|}{4.05} \\
\hline $\mathrm{F}$ dose $\mathrm{x}$ time & \multicolumn{5}{|c|}{$3.417^{*}$} \\
\hline $\boldsymbol{\mu l} \mathbf{L}^{-1}$ & \multicolumn{5}{|c|}{ Phenoxaprope-p-ethyl } \\
\hline 0 & $50.70 \mathrm{aA}$ & $50.30 \mathrm{aA}$ & $51.57 \mathrm{aA}$ & $46.7 \mathrm{bA}$ & $39.67 \mathrm{aB}$ \\
\hline 6,25 & $48.47 \mathrm{aA}$ & $53.43 \mathrm{aA}$ & $51.10 \mathrm{aA}$ & $49.73 \mathrm{abA}$ & $39.83 \mathrm{aB}$ \\
\hline 12,5 & $48.93 \mathrm{aA}$ & $53.70 \mathrm{aA}$ & $52.10 \mathrm{aA}$ & $52.73 \mathrm{aA}$ & $40.73 \mathrm{aB}$ \\
\hline CVC line & \multicolumn{5}{|c|}{5.81} \\
\hline CVC column & \multicolumn{5}{|c|}{4.94} \\
\hline $\mathrm{CV}(\%)$ & \multicolumn{5}{|c|}{5.05} \\
\hline $\mathrm{F}$ dose $\mathrm{x}$ time & \multicolumn{5}{|c|}{$1.21^{\mathrm{ns}}$} \\
\hline
\end{tabular}

Means followed by the same lowercase letter in the column and upwpercase in the line do not differ by Tukey test at $5 \%$ of significance. DAA: Days after application. 
For phenoxaprope-p-ethyl (Table 2) there was no interaction between factors, and the results ranged from 46.70 to $53.70 \mathrm{LCI}$. At the day of product application, it was noted that LCI have increased, probably due to fertilization during implantation. At 7 and 35 DAA no statistical difference was observed between doses and the results remained significantly the same.

Regarding sampling dates, in up to 15 DAA there was no difference in the results, however, at 35 DAA the lowest LCI values were observed. At 15 DAA control showed the lowest LCI values, differing statistically in relation to the highest dose, thus inferring that paclobutrazol stimulates increment of chlorophyll leaves concentration.

This LCI increase with paclobutrazol application is due to some plant physiological responses. Chlorophyll was concentrated in a smaller volume of cells, as paclobutrazol preventing cell stretching and produced compact leaf (Silva et al., 2011; Brito et al., 2016). In addition to this, the increment should be explained as phytol (hydrocarbon present in the side of the chlorophylls) increasing synthesis as it is produced in the same route of gibberellins terpenoids. Concerning the paclobutrazol action, there is great allocation of intermediate compounds that produce phytol in greater quantities and, therefore, occurs a gradual increase in chlorophylls (Silva et al., 2011; Brito et al., 2016; Taiz et al., 2017). Paclobutrazol also stimulates biosynthesis of endogenous cytokinins, maximizing chloroplast differentiation, chlorophyll biosynthesis and delaying degradation (D'arêde et al., 2017).

Despite having varied results in the present study, all are similar to those observed by Dias et al. (2018) working with Carpet grass grown in a protected environment (42.9 to $49.6 \mathrm{LCI}$ ). As for Carpet grass Plus ${ }^{\circledR}$, there are no reference values for comparison with present study data. However, it is essential that when a product is used as a growth regulator, it does not affect the characteristic colour of grass, it does not decrease leaf chlorophyll concentration (Gazola et al., 2016). Thus, it is clear that treatments with paclobutrazol and phenoxaprope-p-ethyl presented levels of LCI equal to greater than control (Table 2). Regardless of the use of any of these products, they will not affect lawn colour as observed through digital image analysis.

The green component, hue and dark green colour index (DGCI) showed that there was no significant interaction between doses and evaluation days (Table 3 ).

Table 3. Digital image analysis of green component $(\mathrm{G})$, hue and dark green colour index (DGCI) of Carpet grass Plus ${ }^{\circledR}$ before and after application of paclobutrazol and phenoxaprope-p-ethyl.

\begin{tabular}{|c|c|c|c|c|c|c|}
\hline \multirow{3}{*}{ Doses } & \multicolumn{2}{|c|}{ Green (G) } & \multicolumn{2}{|c|}{ Hue } & \multicolumn{2}{|c|}{ DGCI } \\
\hline & \multicolumn{2}{|c|}{---- } & \multicolumn{2}{|c|}{$\left({ }^{\circ}\right)$} & \multicolumn{2}{|c|}{--- } \\
\hline & 15 DAA & 35 DAA & 15 DAA & 35 DAA & 15 DAA & 35 DAA \\
\hline $\mathrm{ml} \mathrm{L}^{-1}$ & \multicolumn{6}{|c|}{ Paclobutrazol } \\
\hline 0 & $129 \mathrm{aA}$ & $110 \mathrm{aA}$ & $89 \mathrm{aA}$ & $74 \mathrm{aB}$ & $0.44 \mathrm{aA}$ & $0.34 \mathrm{aB}$ \\
\hline 1.0 & $104 \mathrm{abA}$ & $108 \mathrm{aA}$ & $97 \mathrm{aA}$ & $74 \mathrm{aB}$ & $0.52 \mathrm{aA}$ & $0.31 \mathrm{aB}$ \\
\hline 2.0 & $92 \mathrm{bA}$ & $105 \mathrm{aA}$ & $96 \mathrm{aA}$ & $79 \mathrm{aB}$ & $0.53 \mathrm{aA}$ & $0.36 \mathrm{aB}$ \\
\hline CVC line & \multicolumn{2}{|c|}{28} & \multicolumn{2}{|c|}{7} & \multicolumn{2}{|c|}{0.07} \\
\hline CVC column & \multicolumn{2}{|c|}{34} & \multicolumn{2}{|c|}{9} & \multicolumn{2}{|c|}{0.08} \\
\hline $\mathrm{CV}(\%)$ & \multicolumn{2}{|c|}{17.34} & \multicolumn{2}{|c|}{5.77} & \multicolumn{2}{|c|}{12.15} \\
\hline $\mathrm{F}$ dose $\mathrm{x}$ time & \multicolumn{2}{|c|}{$1.603^{\mathrm{ns}}$} & \multicolumn{2}{|c|}{$1.058^{\mathrm{ns}}$} & \multicolumn{2}{|c|}{$2.539^{\mathrm{ns}}$} \\
\hline $\boldsymbol{\mu} \mathbf{l} \mathbf{L}^{-1}$ & \multicolumn{6}{|c|}{ Phenoxaprope-p-ethyl } \\
\hline 0 & $139 \mathrm{aA}$ & $135 \mathrm{aA}$ & $85 \mathrm{aA}$ & $90 \mathrm{aA}$ & $0.41 \mathrm{aA}$ & $0.45 \mathrm{aA}$ \\
\hline 6,25 & $146 \mathrm{aA}$ & $143 \mathrm{aA}$ & $87 \mathrm{aA}$ & $83 \mathrm{aA}$ & $0.44 \mathrm{aA}$ & $0.39 \mathrm{aA}$ \\
\hline 12,5 & $157 \mathrm{aA}$ & $124 \mathrm{aB}$ & $91 \mathrm{aA}$ & $85 \mathrm{aA}$ & $0.44 \mathrm{aA}$ & $0.44 \mathrm{aA}$ \\
\hline CVC line & \multicolumn{2}{|c|}{30} & \multicolumn{2}{|c|}{9} & \multicolumn{2}{|c|}{0.09} \\
\hline CVC column & \multicolumn{2}{|c|}{37} & \multicolumn{2}{|c|}{11} & \multicolumn{2}{|c|}{0.11} \\
\hline $\mathrm{CV}(\%)$ & \multicolumn{2}{|c|}{14.44} & \multicolumn{2}{|c|}{7.31} & \multicolumn{2}{|c|}{14.55} \\
\hline $\mathrm{F}$ dose $\mathrm{x}$ time & \multicolumn{2}{|c|}{$0.274^{\mathrm{ns}}$} & \multicolumn{2}{|c|}{$0.541^{\text {ns }}$} & \multicolumn{2}{|c|}{$0.615^{\text {ns }}$} \\
\hline
\end{tabular}

Means followed by the same lowercase letter in the column and uppercase in the line do not differ by Tukey test at $5 \%$ of significance. DAA: Days after application. 
For paclobutrazol, there was a decrease in hue and DGCI when compared to 15 and 35 DAA, which is possible to see in Figure 1.

However, the doses used did not differ within each of the evaluated periods. Regardless of the doses, no change on the green colour of the lawn was observed. Thus, paclobutrazol decreased mass production (Table 1) without LCI reduction (Table 2) and without loss of green colour (Table 3) independent of dose $\left(1.0\right.$ and $\left.2.0 \mathrm{ml} \mathrm{L}^{-1}\right)$ at 15 and 35 DAA. Glab et al. (2020) also observed this fact, where they found that the application of paclobutrazol in Ryegrass lawn (Lolium perenne) did not affect grass colour.

In relation to phenoxaprope-p-ethyl, only for green component $(\mathrm{G})$ there was mean decreased from 15 to 35 DAA for dose $2.0 \mathrm{ml} \mathrm{L}^{-1}$, differing from what happened with paclobutrazol, which maintained the indexes at 35 DAA, even after the cut (Table 3). However, with $6.25 \mu \mathrm{L}$ $\mathrm{L}^{-1}$ had a moderate reduction of fresh mass at 15 and 35 DAA (Table 1), maintaining LCI values (Table 2) and green (Table 3), and thus, the aesthetics of the lawn (Figure 2).

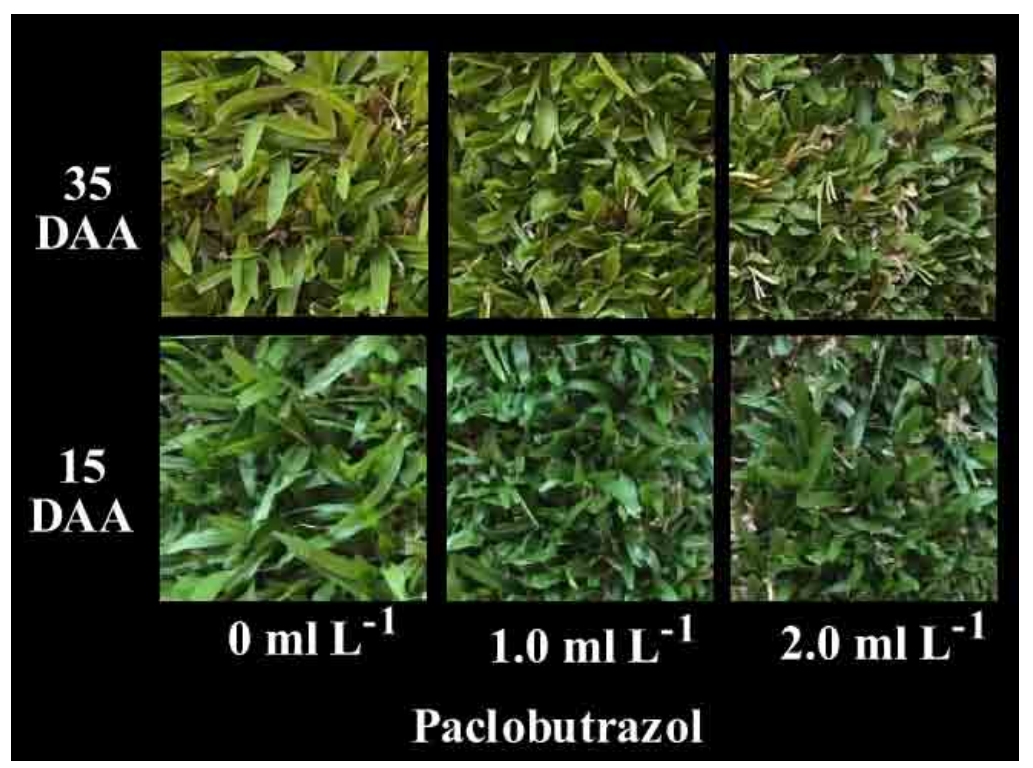

Figure 1. Visual aspect of Carpet grass Plus $^{\circledR}$ after application of Paclobutrazol. DAA- Days after application.

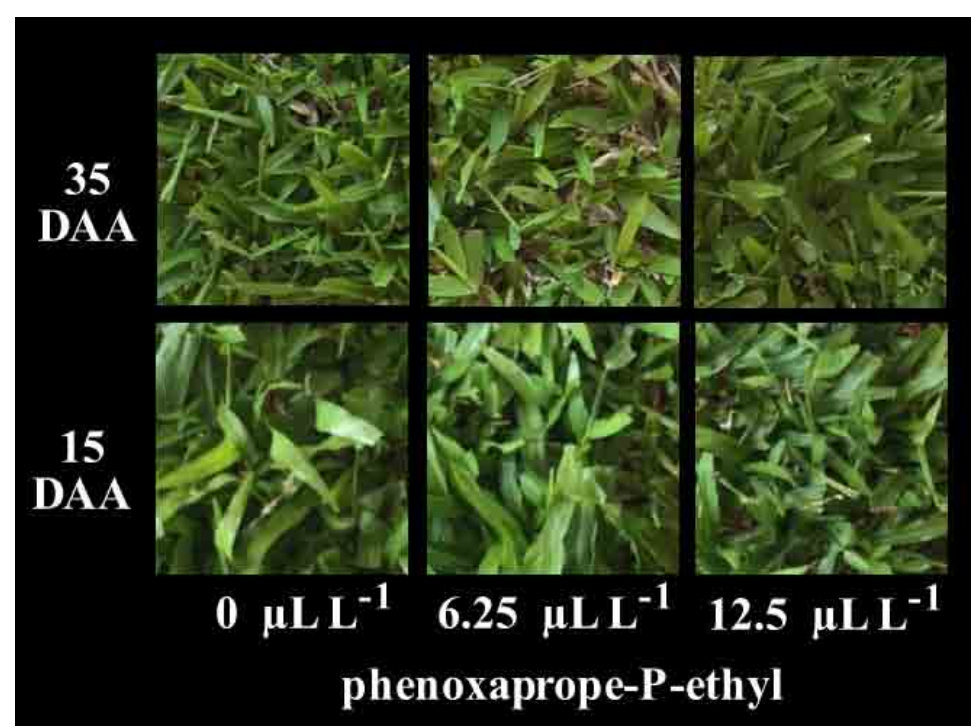

Figure 2. Visual aspect of Carpet grass Plus ${ }^{\circledR}$ after application of phenoxaprope-p-ethyl. DAA- Days after application.

The values of digital image analysis variables, do not present a pattern considered as ideal, as green may vary from 0 to 255 , however, higher values do not represent greater coloration of this colour, because it depends on red and blue combination to reflect the characteristic green (Godoy et al., 2012).
In relation to hue, which describes the colour pigment, did not reach the maximum green value for any of the treatments $\left(120^{\circ}\right)$, however, it was within the range for green colour $\left(60\right.$ to $\left.120^{\circ}\right)$, as it was described by Godoy et al. (2012). 
The DGCI that represents the data of this study vary from $0-1$ and the more close to 1 , the more dark green is reflected. However, unlike other lawns, there is no ideal value, due to reduced number of researches with Carpet grass. For other grass species, the appropriate values of DGCI are $0.50 ; 0.47$ and 0.63 respectively for Emerald grass (Zoysia japonica), St. Augustine grass (Stenotaphrum secundatum) and Bermuda grass (Cynodon spp.) (Godoy et al., 2012). In the present study, the values ranged from 0.31 to 0.53 (Paclobutrazol) and 0.39 to 0.45 (Phenoxaprope-pethyl), being outside the standards for the other mentioned grass.

\section{Conclusions}

The use of paclobutrazol and phenoxaprope-pethyl as a growth regulator in Carpet grass Plus ${ }^{\circledR}$, with the recommended dose of $2.0 \mathrm{ml} \mathrm{L}^{-1}$ and $6.25 \mu \mathrm{L} \mathrm{L}^{-1}$, respectively, provide reduction in leaf mass production, without changing the aesthetics of the lawn and with an increase in the leaf chlorophyll content.

\section{Author Contribution}

MMM: Idea of the experiment, field analysis, data collection and analysis, interpretation of data, critical review. PLFS: Critical review, analysis and interpretation of data, approval of the final version. JCMB: Field analysis, data collection and analysis. MKP: Critical review and translation. RMMC: Critical review, analysis and interpretation of data, approval of the final version, work advisor.

\section{Acknowledgments}

This study was financed partially by the Coordenação de Aperfeiçoamento de Pessoal de Nível Superior - Brasil (CAPES) - Finance Code 001.

The authors are grateful to the Bayer ${ }^{\circledR}$, in the person of forest engineer Fabricio Sebok; Forth Jardim ${ }^{\circledR}$ in the person of agronomist engineer Marcos Feliciano; Itograss ${ }^{\circledR}$ in the person of agronomist engineer Éder Pires and the Faculdade de Ciências Agronômicas (UNESP) Botucatu-SP, for the collaboration to carry out the experiment.

\section{References}

AFFONSO, C.H.A.; FREITAS, L.G. B. Implantação e manejo de gramíneas em estradas e rodovias. In: VILLAS BÔAS, R.L.; GODOY, L.J. SIGRA: Produção, Implantação e Manutenção. Botucatu: GEMFER, 2003. p.194-201.

ANTONIOLLI, D. Manual para aquisição, instalação e manutenção de gramas. Especial: rodovias e áreas de segurança. São Paulo: Associação Nacional Grama Legal, 2019. 12p.
BRITO, C.L.L.; MATSUMOTO, S.N.; SANTOS, J.L.; GONÇALVES, D.N.; RIBEIRO, A.F.F. Effect of paclobutrazol in the development of ornamental sunflower. Revista de Ciências Agrárias, v.39, n.1, p.153-160, 2016. DOI: http://dx.doi.org/10.19084/RCA15044

CASTRO, A.P.A.; RODRIGUES, R.A.; BEZERRA, B.S. Proposição de um checklist para gestão de taludes em projetos rodoviários. Revista Nacional de Gerenciamento de Cidades, v.3, n.14, p.1-13, 2015. DOI: http://dx.doi. org/10.17271/231884723142015933

D'ARÊDE, L.O.; MATSUMOTO, S.N.; SANTOS, J.L.; VIANA, A.E.S.; SILVA, P.A.R. Morfofisiologia do crescimento vegetativo inicial de cafeeiros arábica submetidos à aplicação via foliar de paclobutrazol. Coffee Science, v.12, n.4, p.451-462, 2017. DOI: https://doi. org/10.25186/cs.v12i4.1311

DIAS, J. A.C.; SANTOS, P.L.F.; CASTILHO, R.M.M. Resposta da grama São Carlos em função do cultivo em diferentes substratos com e sem adubação química. Tecnologia \& Ciência Agropecuária, v.9, n.2, p.27-30, 2015.

DIAS, J.A.C.; SANTOS, P.L.F.; GAZOLA, R.P.D.; SARAIVA, B.C.; CASTILHO, R.M.M. Substrates and fertilization in the development of São Carlos grass. Scientific Electronic Archives, v.11, n.6, 2018. DOI: http:// dx.doi.org/10.36560/1162018587

DIAS, R.C.; DADAZIO, T.S.; TROPALDI, L.; CARBONARI, C.A.; VELINI, E.D. Glyphosate as growth regulator for Bahiagrass and Broadleaf Carpetgrass. Planta Daninha, v.37, e019213829, p.1-10, 2019. DOI: https:// doi.org/10.1590/S0100-83582019370100144

DINALLI, R.P.; BUZETTI, S.; GAZOLA, R.N.; CASTILHO, R.M.M.; CELESTRINO, T. S.; DUPAS, E.; TEIXEIRA FILHO, M. C. M.; LIMA, R. C. Application of herbicides as growth regulators of emerald Zoysia grass fertilized with nitrogen. Semina: Ciências Agrárias, v.36, n.3, suplemento 1, p.1875-1894, 2015. DOI: https://doi. org/10.5433/1679-0359.2015v36n3Supl1p1875

FERREIRA, D.F. SISVAR: A computer analysis system to fixed effects Split plot type designs. Revista Brasileira de Biometria, v.37, n.4, p.529-535, 2019. DOI: https://doi. org/10.28951/rbb.v37i4.450

GAZOLA, R.P.D.; BUZETTI, S.; GAZOLA, R.N.; CASTILHO, R.M.M.; TEIXEIRA FILHO, M.C.M.; CELESTRINO, T.S.; DUPA, E. Nitrogen dose and type of herbicide used for growth regulation on the green coloration intensity of Emerald grass. Ciência Rural, v.46, n.6, p.984-990, 2016. DOI: http://dx.doi.org/10.1590/0103$8478 \mathrm{cr} 20150276$ 
GAZOLA, R.P.D.; BUZETTI, S.; GAZOLA, R.N.; CASTILHO, R.M.M.; TEIXEIRA FILHO, M.C.M.; CELESTRINO, T.S. Nitrogen fertilization and glyphosate doses as growth regulators in Esmeralda grass. Revista Brasileira de Engenharia Agrícola e Ambiental, v.23, n.12, p.930-936, 2019. DOI: https://doi.org/10.1590/18071929/agriambi.v23n12p930-936

GLAB, T.; SZEWCZYK, W.; GONDEK, K.; KNAGA, J.; TOMASIK, M.; KOWALIK, K. Effect of plant growth regulators on visual quality of turfgrass. Scientia Horticulturae, v.267, p.1-10, 2020. DOI: https://doi. org/10.1016/j.scienta.2020.109314

GODOY, L.J.G.; VILLAS BÔAS, R.L.; BACKES, C.; SANTOS, A.J.M. Nutrição, Adubação e Calagem para produção de gramas. Botucatu: FEPAF, 2012. 146p.

ITOGRASS. São Carlos Plus ${ }^{\circledR}$. Available at: <https:// itograss.com.br/grama-sao-carlos-plus/>. Accessed on: February $29^{\text {th }} 2020$.

JOHNSON, B.L. Response of Tifway bermudagrass to rate and frequency of flurprimidol and paclobutrazol application. HortScience, v.27, n.3, p.230-233, 1992.

KARCHER, D.E., RICHARDSON, M.D. Quantifying turfgrass color using digital image analysis. Crop Science, v.43, p.943-951, 2003. DOI: https://doi.org/10.2135/ cropsci2003.9430

KREUSER, B.I.L.L. Effective use of plant growth regulators on golf putting greens. Green Section Record, v.53, n.7, p.1-10, 2015.

MARCHI, S.R.; SILVA JUNIOR, A.C.; MARTINS, D. Development of different grass species with the use of the growth regulator Trinexapac-Ethyl. Planta Daninha, v.35, e017156520, p.1-8, 2017. DOI: https://doi.org/10.1590/ S0100-83582017350100071

MARQUES, K.D.M.; MOREIRA, W.C.L.; SILVA, J.F.; MOREIRA, J.G.V.; MELHORANÇA FILHO, A.L. Efeito hormético de glyphosate no crescimento inicial de mudas de paricá (Schizolobium amazonicum). Agrarian, v.13, n.47, p.9-16, 2020. DOI: https://doi.org/10.30612/agrarian. v13i47.8074

McCUllOUGH, P.E.; LIU, H.; MCCARTY, L.B.; WHITWELL, T. Response of 'TifEagle' bermudagrass to seven plant growth regulators. HortScience, v.39, n.7, p.1759-1762, 2004. DOI: https://doi.org/10.1590/10.21273/ HORTSCI.39.7.1759

MCELROY, S. Reguladores de crescimento e controle de plantas em gramados. In: BACKES, C.; GODOY, L.J.G.; MATEUS, C.M.D.; SANTOS, A.J.M.; VILLAS BÔAS, R.L.; OLIVEIRA, M.R. Tópicos atuais em gramados III. Botucatu: FEPAF, 2012. p. 71-79.
OLIVEIRA, N.B.; OLIVEIRA, J.F.V.; SANTOS, P.L.F.; GAZOLA, R.P.D.; CASTILHO, R.M.M. Avaliação do estado nutricional de três gramados ornamentais em Ilha Solteira-SP: um estudo de caso. Revista LABVERDE, v.9, n.1, p.96-119, 2018. DOI: http://dx.doi.org/10.11606/ issn.2179-2275.v9i1p96-119

BAYER. PODIUM EW. Frankfurt: Höschst, [2019]. Bula de defensivo. 13p. Available at: $<$ http://www.adapar. pr.gov.br/arquivos/File/defis/DFI/Bulas/Herbicidas/ PODIUMEW1119.pdf $>$. Accessed on: February $29^{\text {th }} 2020$.

QUEIROZ, J.R.G.; SILVA JÚNIOR, A.C.; MARTINS, D. Use of Prohexadione Calcium on grass species development. Planta Daninha, v.35, e017161877, p.1-9, 2017. DOI: https://doi.org/10.1590/S0100-83582017350100072

SANTOS, P.L.F.; BARCELOS, J.P.Q.; CASTILHO, R.M.M. Diferentes substratos de um gramado ornamental para uso em telhados verdes. Periódico Técnico e Científico Cidades Verdes, v.4, n.10, p.81-94, 2016. DOI: http://dx.doi.org/10.17271/2317860441020161393

SANTOS, P.L.F.; CASTILHO, R.M.M. Substrates in the development of a sports turfgrass "Tifton 419". Ornamental Horticulture, v.24, n.4, p.138-144, 2018. DOI: https://doi.org/10.14295/oh.v24i2.1155

SEMILLAS FITÓ. Áreas verdes: guía técnica de cultivo. 5ed. Barcelona: Catálago Semillas Fitó, 2010. 49p.

SILVA, J.C.; GERLACH, G.A.C.; RODRIGUES, R.A.F.; ARF, O. Influência de doses reduzidas e épocas de aplicação sobre o efeito hormético de glyphosate em feijoeiro. Revista de la Facultad de Agronomía, v.115, n.2, p.191-199, 2016.

SILVA, K.J.P.; PUIATTI, M.; FREITAS, A.R.J.; GROSSI, J.A.S; CECON, P.R. Avaliação dos teores de clorofila e desenvolvimento de plantas de pepino submetidas à aplicação de Paclobutrazol. Horticultura Brasileira, v.29, n.2, p. S2200-S2206, 2011.

SOUZA, F.H.D.; GUSMÃO, M.R.; MATTA, F.P.; CASTRO, A.C.R.; MITTELMANN, A.; FÁVERO, A. P.; JANK, L. Atributos desejáveis para gramados a serem cultivados sob condições brasileiras: uma proposta. Ornamental Horticulture, v.22, n.2, p.154-165, 2016. DOI: https://doi.org/10.14295/oh.v22i2.841

TAIZ, L.; ZEIGER, E.; MÜLLER, I.M.; MURPHY, A. Fisiologia e desenvolvimento vegetal. 6ed. Porto Alegre: Artmed, 2017. 858p. 